\title{
BMR
}

\section{Synonymous single nucleotide polymorphisms in the $M C 4 R$ gene that are significantly associated with milk production traits in water buffaloes}

\author{
T.X. Deng ${ }^{1 *}$, C.Y. Pang1*, M.Q. Liu ${ }^{2}$, C. Zhang ${ }^{2}$ and X.W. Liang ${ }^{1}$ \\ ${ }^{1}$ Guangxi Provincial Key Laboratory of Buffalo Genetics, \\ Breeding and Reproduction Technology, Buffalo Research Institute, \\ Chinese Academy of Agricultural Sciences, Nanning, China \\ ${ }^{2}$ Guangdong Provincial Key Lab of Agro-Animal Genomics and Molecular \\ Breeding, South China Agriculture University, Guangzhou, China \\ *These authors contributed equally to this study. \\ Corresponding author: X.W. Liang \\ E-mail: liangbri@126.com
}

Genet. Mol. Res. 15 (2): gmr.15028153

Received December 17, 2015

Accepted February 11, 2016

Published July 15, 2016

DOI http://dx.doi.org/10.4238/gmr.15028153

\begin{abstract}
Melanocortin-4 receptor (MC4R) is associated with feed intake, growth, fatness, and carcass composition in many domestic animals. The aim of this study was to evaluate the association of single nucleotide polymorphisms (SNPs) in $M C 4 R$ with milk production traits in water buffalo. Eight SNPs were identified by direct polymerase chain reaction sequencing of samples from 18 buffaloes. SNPs were then genotyped using the matrix-assisted laser desorption/ionization time of flight mass spectrometry (MALDI-TOF MS) method in 332 buffaloes. Two of eight SNPs were not in HardyWeinberg equilibrium. Based on the SNP data, seven haplotypes were constructed. Three SNPs H1 (AGT), H2 (GAT), and H3 (GAC) accounted for $93.0 \%$ of the total individuals. Statistical analysis
\end{abstract}


indicated that the SNP g.1104C $>$ T was significantly associated with milk yield, protein, and fat percentage $(\mathrm{P}<0.05)$. In conclusion, these results provide evidence that polymorphisms in the buffalo $M C 4 R$ gene are associated with milk production traits and might be potential biomarkers for water buffalo breeding.

Key words: Buffalo; Milk production; $M C 4 R$ gene; SNP; Haplotype

\section{INTRODUCTION}

Buffaloes are an important livestock species for Asian populations, contributing to meat, milk, and draught power. Milk production and milk quality are the most important features used to evaluate production performance in buffaloes (Gil et al., 2013). Milk production traits in dairy cattle should be improved as a result of genetic progress, whereby major genes or genetic markers associated with these traits are identified and applied (Li et al., 2012). However, few studies have investigated candidate genes for milk production traits in water buffalo (Pauciullo et al., 2012). It is therefore necessary to analyze and assess candidate genes that contribute to the breeding value of milk buffalo.

Melanocortin-4 receptor $(M C 4 R)$, a G-protein-coupled receptor, is involved in appetite regulation and energy balance (Barb et al., 2004; Seeley et al., 2004; Razquin et al., 2011). In humans, more than 150 mutations in the $M C 4 R$ gene have been found, some of which are associated with obesity (Huang et al., 2010). The 1426G $>$ A mutation in the $M C 4 R$ gene has been associated with feed intake, growth, fatness, and carcass composition in porcine individuals (Van den Maagdenberg et al. 2007; Piórkowska et al., 2010). Similarly, many single nucleotide polymorphisms (SNPs) have been identified that are associated with body weight, carcass weight, and back fat thickness in cattle (Liu et al., 2010), sheep (Song et al., 2012), and chicken (Yan et al., 2013).

However, there have been no reports on SNPs in the $M C 4 R$ gene or on their genetic effects on economic traits in water buffaloes. The aim of this study was to identify SNPs in the $M C 4 R$ gene of Chinese buffaloes using polymerase chain reaction (PCR) sequencing and matrix-assisted laser desorption/ionization time of flight mass spectrometry (MALDI-TOF MS). Moreover, analyses of marker-trait associations were performed in the buffalo population to find potential molecular markers in the $M C 4 R$ gene for milk production traits.

\section{MATERIAL AND METHODS}

\section{Animals and phenotypic records}

The study was approved by the Animal Ethics Committee of Buffalo Research Institute, Chinese Academy of Agricultural Sciences (BRI-CAAS). In total, 332 milk buffaloes were selected from a farm belonging to the BRI-CAAS. Phenotypic data for three milk production traits were collected at BRI-CAAS during a 6-year period (January 2007 to December 2012). Genomic DNA was extracted from whole blood samples of buffaloes using TIANamp Blood DNA Kit (Tiangen, China). The DNA quality was measured using a NanoDrop 2000 (GENE, USA). 


\section{SNP detection and genotyping}

Eighteen buffaloes were randomly selected for PCR amplification and sequencing. Two pairs of primers (MC4R_F1: CGGAGAAGAAGCATCTTGCA, MC4R_R1: GGGCATAAATCAGAGGGTCA; MC4R_F2: TCTTGTCCCCAGAACCCATA, MC4R_R2: TTCTGCACAGGAAGAATGAATG) were designed to identify genetic polymorphisms in the buffalo MC4R gene (GenBank accession No. KJ139982.1) using the Primer Premier 5.0 software. PCR was performed in $50-\mu \mathrm{L}$ reaction mixtures, containing $1 \mu \mathrm{L}$ genomic DNA

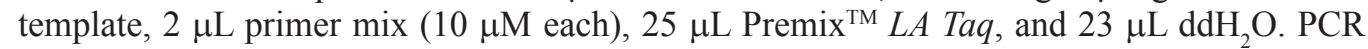
was run in an ABI PCR machine using the following program: 3 min at $94^{\circ} \mathrm{C} ; 35$ cycles of $30 \mathrm{~s}$ at $94^{\circ} \mathrm{C}, 30 \mathrm{~s}$ at $56^{\circ}-59^{\circ} \mathrm{C}$, and $45 \mathrm{~s}$ at $72^{\circ} \mathrm{C}$; and a final extension of $8 \mathrm{~min}$ at $72^{\circ} \mathrm{C}$. DNA sequence alignment was performed using the SeqMan software (DNAStar) to detect polymorphisms.

A total of 332 buffaloes were genotyped by MALDI-TOF assay (Sequenom Inc., San Diego, CA, USA) by Invitrogen (Guangzhou, China).

\section{Statistical analyses}

Allelic frequencies, genotypic frequencies, polymorphism information content (PIC), and Hardy-Weinberg equilibrium (HWE) were determined using R language within the genetics package (Foulkes, 2009). Haplotype blocks, haplotype frequencies, and linkage disequilibrium (LD) of SNPs were analyzed using the Haploview v.4.2 software (Barrett et al., 2005).

Marker-trait association analyses were performed in SAS V9.4 (SAS Institute Inc., Cary, NC, USA). The genetic effects were analyzed using the following GLM model:

$$
Y_{i j k l m}=\mu+Y_{i}+P_{j}+S_{k}+D I M_{l}+G_{m}+e_{i j k l m}
$$

(Equation 1)

where $Y_{i j k l m}=$ milk production traits observed; $\mu$ = overall mean; $Y_{i}=$ fixed effect of the $i$ th year of production; $P_{j}=$ fixed effect of the $j$ th parity (5 classes: $\left.1-4,>4\right) ; S_{k}=$ fixed effect of the $k$ th season (4); $D I M_{l}^{\prime}=$ fixed effect of the $l$ th stage if lactation (5 groups: $1-120,121-180,181-240$, $241-300,>300) ; G_{m}=$ fixed effect of the $m$ th genotype; $e_{i j k l m}=$ random residual.

\section{RESULTS}

\section{Discovery and genotyping of SNPs}

In the present study, eight SNPs were identified in the buffalo $M C 4 R$ gene. Four SNPs (g.345A $>$ G, g.762G $>$ A, g.864G $>$ T, and g. 1104C $>$ T) were located in the exon regions and were synonymous mutations. The others (g.138A $>\mathrm{G}$ and g.226C $>\mathrm{T} ; \mathrm{g} 1340 . \mathrm{T}>\mathrm{G}$, and g.1525A $>\mathrm{G}$ ) were located in the 5 'untranslated region (UTR) or 3'-UTR, respectively (Figure 1A). SNPs were genotyped in 332 individuals based on the MALDI-TOF method with an average genotyping success rate of $98.3 \%$. Data on genotypes and allelic frequency are summarized in Table 1. Both g.226C $>\mathrm{T}$ and g. $1525 \mathrm{~A}>\mathrm{G}$ were not in HWE, whereas the genotypes and allele frequencies of the other six SNPs were consistent with HWE $(\mathrm{P}>0.05)$. The results of 
PIC analysis showed that four SNPs (g.345A $>$ G, g.762G $>$ A, g.1104C $>$ T, and g.1340T $>$ G) should be considered as moderate polymorphisms, and the other SNPs should be deemed low polymorphisms. These results indicate that the diversity of the buffalo $M C 4 R$ gene in the analyzed populations was low.

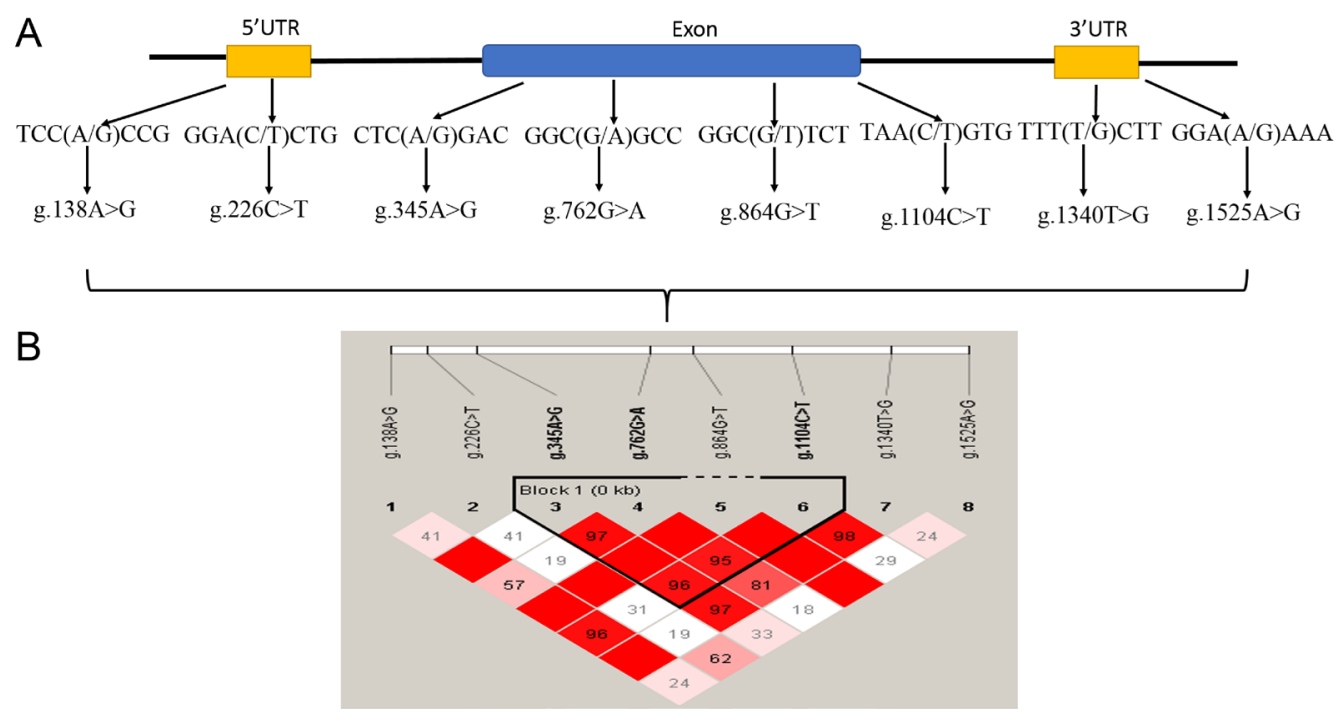

Figure 1. Structure and haplotype analyses of the buffalo $M C 4 R$ gene. A. Orange boxes represent the 5'-untranslated region (UTR) and 3'-UTR, and the blue box represents the exon. Arrows show the positions of eight single nucleotide polymorphisms (SNPs), and the parentheses indicate the types of SNPs; B. Linkage disequilibrium (LD) blocks are denoted by triangles. Values in the diamond are D' x 100 between pairs of SNPs. Empty diamonds indicate $\mathrm{D}^{\prime}=1$ (i.e., complete LD between two SNPs).

Table 1. Genotypes and allelic frequencies of eight SNPs in the $M C 4 R$ gene within the studied breeds.

\begin{tabular}{|c|c|c|c|c|c|c|c|}
\hline \multirow{3}{*}{$\begin{array}{l}\text { Locus } \\
\text { g.138A }>\mathrm{G}\end{array}$} & \multicolumn{3}{|c|}{ Genotype frequency (n) } & \multicolumn{2}{|c|}{ Allelic frequency } & \multirow{3}{*}{$\begin{array}{c}\text { HWE P value } \\
0.38\end{array}$} & \multirow{2}{*}{$\begin{array}{c}\text { PIC P value } \\
0.20\end{array}$} \\
\hline & AA (248) & AG (80) & GG (4) & $\mathrm{A}$ & $\mathrm{G}$ & & \\
\hline & 0.75 & 0.24 & 0.01 & 0.87 & 0.13 & & \\
\hline \multirow[t]{2}{*}{ g. $226 \mathrm{C}>\mathrm{T}$} & CC (299) & CT (22) & TT (11) & $\mathrm{C}$ & $\mathrm{T}$ & \multirow[t]{2}{*}{0.00} & \multirow[t]{2}{*}{0.13} \\
\hline & 0.90 & 0.07 & 0.03 & 0.93 & 0.07 & & \\
\hline \multirow[t]{2}{*}{ g. $345 \mathrm{~A}>\mathrm{G}$} & AA (94) & AG (172) & GG (66) & A & $\mathrm{G}$ & \multirow[t]{2}{*}{0.43} & \multirow[t]{2}{*}{0.37} \\
\hline & 0.28 & 0.52 & 0.20 & 0.54 & 0.46 & & \\
\hline \multirow[t]{2}{*}{ g. $762 \mathrm{G}>\mathrm{A}$} & GG (112) & GA (168) & AA (52) & $\mathrm{G}$ & A & \multirow[t]{2}{*}{0.40} & \multirow[t]{2}{*}{0.37} \\
\hline & 0.34 & 0.51 & 0.16 & 0.59 & 0.41 & & \\
\hline \multirow[t]{2}{*}{ g.864G $>\mathrm{T}$} & GG (309) & GT (23) & TT $(0)$ & $\mathrm{G}$ & $\mathrm{T}$ & \multirow[t]{2}{*}{0.51} & \multirow[t]{2}{*}{0.06} \\
\hline & 0.93 & 0.07 & - & 0.97 & 0.03 & & \\
\hline \multirow[t]{2}{*}{ g. $1104 C>T$} & CC (68) & CT (165) & TT (99) & $\mathrm{C}$ & $\mathrm{T}$ & \multirow[t]{2}{*}{0.96} & \multirow[t]{2}{*}{0.27} \\
\hline & 0.20 & 0.50 & 0.30 & 0.45 & 0.55 & & \\
\hline \multirow[t]{2}{*}{ g.1340T $>\mathrm{G}$} & TT (40) & TG (142) & GG (150) & $\mathrm{T}$ & G & \multirow[t]{2}{*}{0.48} & \multirow[t]{2}{*}{0.35} \\
\hline & 0.12 & 0.43 & 0.45 & 0.67 & 0.33 & & \\
\hline \multirow[t]{2}{*}{ g. $1525 \mathrm{~A}>\mathrm{G}$} & AA (293) & AG (29) & GG (10) & A & G & \multirow[t]{2}{*}{0.00} & \multirow[t]{2}{*}{0.19} \\
\hline & 0.88 & 0.09 & 0.03 & 0.93 & 0.03 & & \\
\hline
\end{tabular}

$\mathrm{HWE}=$ Hardy-Weinberg equilibrium; PIC = polymorphism information content. 


\section{Linkage disequilibrium and haplotype construction}

To reveal linkage relationships between the eight SNPs, LD was estimated for this population. The results showed that the $\mathrm{D}^{\prime}$ values ranged from 0.18 to 0.98 (Figure 1B). Three SNPs (g.345A $>$ G, g.762G $>$ A, and g.1104C $>$ T) were in high LD $\left(D^{\prime}>0.9\right)$. Next, the haplotypes of the three SNPs were constructed in all analyzed populations. As illustrated in Figure 2, the haplotypes H1 (AGT), H2 (GAT), and H3 (GAC) were in the top three, accounting for $93.0 \%$ of the total individuals. The remaining haplotypes were excluded from further analyses based on the percentages of referring haplotype combinations being lower than $5.0 \%$.

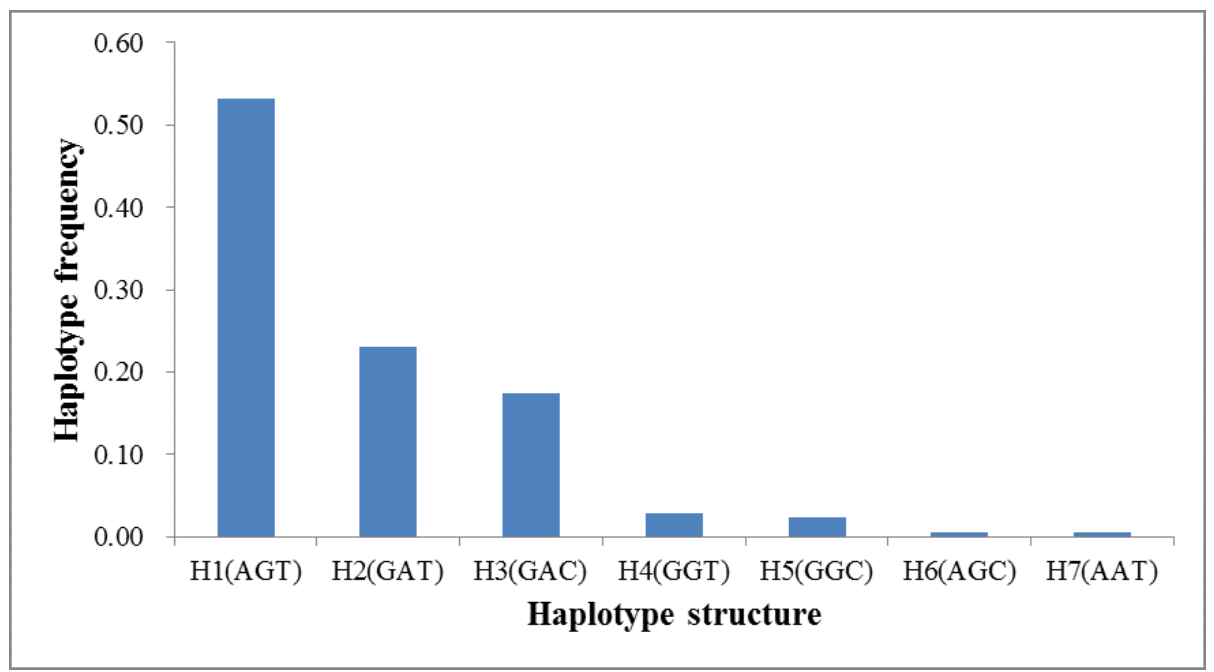

Figure 2. Haplotype frequencies of polymorphisms in the $M C 4 R$ gene.

\section{Association analysis}

Least squares mean values for genetic variants in the population associated with milk production traits are given in Table 2. Our analysis suggested that the SNP g. 1104C $>$ T was significantly associated with milk yield and two other milk composition traits (protein and fat percentage) $(\mathrm{P}<0.05)$. Bonferroni analysis revealed that milk buffaloes with the heterozygous genotype, CT, at the g.1104C $>\mathrm{T}$ locus had a significantly higher 305-day milk yield than those with the homozygous TT and CC genotypes. Milk buffaloes with the CC genotype showed the highest protein and fat percentage $(\mathrm{P}<0.05)$. The heterozygous genotype at g.1104C $>\mathrm{T}$ showed better performance than the homozygous genotype for milk yield, whereas the homozygous genotype presented higher protein and fat percentages in Chinese buffaloes.

Based on the haplotype data presented in Figure 1B, combination analysis of haplotypes H1, H2, and $\mathrm{H} 3$ was performed (Table 3). The result revealed that the haplotype block was significantly associated with milk yield and protein percentage $(\mathrm{P}<0.05)$. The 305-day milk yield in milk buffaloes with the diplotype $\mathrm{H} 1 \mathrm{H} 2$ was higher than in the other diplotypes. Milk buffaloes with the diplotype $\mathrm{H} 3 \mathrm{H} 3$ had a higher protein percentage than those with the $\mathrm{H} 1 \mathrm{H} 1$ and $\mathrm{H} 1 \mathrm{H} 2$ combinations. These findings provide additional evidence to support SNP g. $1104 \mathrm{C}>\mathrm{T}$ having a significant effect on milk production traits. 
Table 2. Association analysis between the genotypes of eight SNPs and three traits in the studied population.

\begin{tabular}{|c|c|c|c|c|}
\hline \multirow[t]{2}{*}{ Locus } & \multirow[t]{2}{*}{ Genotype (N) } & \multicolumn{3}{|c|}{ Milk traits $(\mathrm{LSM} \pm \mathrm{SE})$} \\
\hline & & 305-day MY (kg) & $\% \mathrm{P}$ & $\% \mathrm{~F}$ \\
\hline \multirow[t]{3}{*}{ g. $138 \mathrm{~A}>\mathrm{G}$} & AA (248) & $1531.73 \pm 43.96$ & $4.35 \pm 0.05$ & $7.51 \pm 0.14$ \\
\hline & GA (80) & $1449.70 \pm 61.05$ & $4.37 \pm 0.08$ & $7.62 \pm 0.20$ \\
\hline & GG (4) & $1364.96 \pm 219.11$ & $4.53 \pm 0.27$ & $7.83 \pm 0.72$ \\
\hline \multirow[t]{3}{*}{ g. $226 \mathrm{C}>\mathrm{T}$} & CC (295) & $1514.81 \pm 43.35$ & $4.32 \pm 0.05$ & $7.46 \pm 0.14$ \\
\hline & TC (26) & $1458.67 \pm 89.20$ & $4.49 \pm 0.11$ & $7.80 \pm 0.29$ \\
\hline & TT (11) & $1616.84 \pm 132.96$ & $4.58 \pm 0.16$ & $8.18 \pm 0.43$ \\
\hline \multirow[t]{3}{*}{ g. $345 \mathrm{~A}>\mathrm{G}$} & AA (94) & $1466.54 \pm 56.79$ & $4.29 \pm 0.07$ & $7.42 \pm 0.19$ \\
\hline & GA (172) & $1569.35 \pm 48.34$ & $4.33 \pm 0.06$ & $7.41 \pm 0.16$ \\
\hline & GG (66) & $1441.78 \pm 62.62$ & $4.51 \pm 0.08$ & $7.96 \pm 0.20$ \\
\hline \multirow[t]{3}{*}{ g. $762 \mathrm{G}>A$} & $\mathrm{AA}(52)$ & $1463.95 \pm 70.57$ & $4.52 \pm 0.09$ & $7.79 \pm 0.23$ \\
\hline & GA (168) & $1557.72 \pm 46.75$ & $4.34 \pm 0.06$ & $7.49 \pm 0.15$ \\
\hline & GG (112) & $1448.69 \pm 54.52$ & $4.32 \pm 0.07$ & $7.51 \pm 0.18$ \\
\hline \multirow[t]{2}{*}{ g. $864 \mathrm{G}>\mathrm{T}$} & GG (309) & $1523.19 \pm 43.41$ & $4.34 \pm 0.05$ & $7.49 \pm 0.14$ \\
\hline & GT (23) & $1423.11 \pm 93.58$ & $4.50 \pm 0.12$ & $7.89 \pm 0.31$ \\
\hline \multirow[t]{3}{*}{ g. $1104 \mathrm{C}>\mathrm{T}$} & $\mathrm{CC}(68)$ & $1450.26 \pm 61.48^{\mathrm{a}}$ & $4.50 \pm 0.08^{\mathrm{a}}$ & $7.92 \pm 0.20^{\mathrm{a}}$ \\
\hline & CT (167) & $1585.00 \pm 48.59^{\mathrm{ab}}$ & $4.33 \pm 0.06^{\mathrm{a}}$ & $7.44 \pm 0.16^{\mathrm{ab}}$ \\
\hline & TT (97) & $1442.05 \pm 56.23^{\mathrm{a}}$ & $4.28 \pm 0.07^{\mathrm{ab}}$ & $7.37 \pm 0.18^{\mathrm{ab}}$ \\
\hline \multirow[t]{3}{*}{ g. $1340 \mathrm{~T}>\mathrm{G}$} & GG (150) & $1520.29 \pm 50.01$ & $4.34 \pm 0.06$ & $7.57 \pm 0.16$ \\
\hline & GT (142) & $1521.28 \pm 50.37$ & $4.34 \pm 0.06$ & $7.39 \pm 0.16$ \\
\hline & TT (40) & $1432.88 \pm 79.57$ & $4.55 \pm 0.10$ & $8.05 \pm 0.26$ \\
\hline \multirow[t]{2}{*}{ g. $1525 \mathrm{~A}>\mathrm{G}$} & AA (293) & $1543.72 \pm 45.04$ & $4.31 \pm 0.06$ & $7.45 \pm 0.15$ \\
\hline & GG (39) & $1398.07 \pm 72.35$ & $4.51 \pm 0.09$ & $7.86 \pm 0.24$ \\
\hline
\end{tabular}

${ }^{\mathrm{a}, \mathrm{b}}$ Values followed by different superscripts within columns differ significantly $(\mathrm{P}<0.05)$. MY = milk yield; $\mathrm{P}=$ protein; $\mathrm{F}=$ fat.

Table 3. Genetic effects of haplotype combinations among the three SNPs in MC4R on milk traits in water buffaloes.

\begin{tabular}{l|c|c|c}
\hline Haplotype combination $(\mathrm{N})$ & 305-day MY $(\mathrm{kg})$ & $\% \mathrm{P}$ & $\% \mathrm{~F}$ \\
\hline $\mathrm{H} 1 \mathrm{H} 1(92)$ & $1427.18 \pm 57.44^{\mathrm{a}}$ & $4.31 \pm 0.07^{\mathrm{a}}$ & $7.40 \pm 0.19$ \\
\hline $\mathrm{H} 1 \mathrm{H} 2(152)$ & $1586.57 \pm 49.51^{\mathrm{ab}}$ & $4.33 \pm 0.06^{\mathrm{a}}$ & $7.36 \pm 0.16$ \\
\hline $\mathrm{H} 3 \mathrm{H} 3(50)$ & $1428.24 \pm 71.50^{\mathrm{a}}$ & $4.54 \pm 0.09^{\mathrm{ab}}$ & $7.76 \pm 0.24$ \\
\hline $\mathrm{P}$ value & 0.0060 & 0.0431 & 0.2062 \\
\hline
\end{tabular}

${ }^{a, b}$ Values followed by different superscripts within columns differ significantly $(\mathrm{P}<0.05)$. MY: milk yield; $\mathrm{P}$ : protein; F: fat.

\section{DISCUSSION}

$M C 4 R$ signaling mediates the effects of leptin on food intake, which can regulate fatness and body weight (Choi et al., 2003). Milk composition is a variable trait that depends on the regulation of feeding behavior and fat metabolism. This study was the first to evaluate the effect of SNPs in the MCAR gene on milk production traits in water buffaloes. $M C 4 R$ gene polymorphisms are highly frequent in both humans and animals. In humans, more than 150 mutations in the $M C 4 R$ gene have been found, and some have been associated with obesity (Chambers et al., 2008). We identified eight SNPs in the buffalo $M C 4 R$ gene; four were located in the exon regions and were synonymous mutations, and two in the 5'-UTR and 3'-UTR.

Haplotype data are valuable for assessing the effects of genes on economic traits. For the MC4R gene, Cai et al. (2015) reported that the haplotypes CGACG and CTCCC were associated with increased body weight and average daily gain in yaks. In this study, statistical analyses showed that in milk buffaloes, diplotype $\mathrm{H} 1 \mathrm{H} 2$ was the most significantly associated with 305-day milk yield $(\mathrm{P}<0.05)$, and individuals with diplotype $\mathrm{H} 3 \mathrm{H} 3$ showed the highest protein percentage compared to the $\mathrm{H} 1 \mathrm{H} 1$ and $\mathrm{H} 1 \mathrm{H} 2$ haplotype combinations. These results 
imply that the SNP g. $1104 \mathrm{C}>\mathrm{T}$ in the $M C 4 R$ gene has potential for application in early buffalo marker-associated selection programs.

Genetic variations in the UTR, or synonymous mutations in exons, can affect phenotypes in animals (Hunt et al., 2009; Dubey et al., 2013; Vislovukh et al., 2014). Two linked SNPs (g.293C $>$ G and g.129A $>$ G) in the 5'-UTR of the $M C 4 R$ gene were associated with body weight and daily gain in 6 -month-old Nanyang cattle $(\mathrm{P}<0.05)$ (Zhang et al., 2009). Zuo et al. (2014) reported that the $1016 \mathrm{G}>$ A mutation in the 3 '-UTR was significantly associated with body weight, average daily gain, and back fat thickness. Among these eight SNPs in water buffaloes, we found that the SNP g.1104C $>$ T had significant effects on milk yield and on two milk composition traits (protein percentage and fat percentage) $(\mathrm{P}<0.05)$. Milk buffaloes with the heterozygous genotype CT at the g.1104C $>\mathrm{T}$ locus had a higher 305-day milk yield than those with the homozygous TT and CC genotypes, whereas the $\mathrm{CC}$ genotype presented the highest protein and fat percentages $(\mathrm{P}<0.05)$. These results are consistent with synonymous mutations in $M C 4 R$ in other animals. Seong et al. (2012) reported that two "silent" SNPs (g.927C $>\mathrm{T}$ and g.1786C $>\mathrm{T}$ ) in the $M C 4 R$ gene in Korean cattle significantly influenced marbling score and back fat, respectively. Similar results have also been reported in dogs (g.895C > T) (Zeng et al., 2014). Szyndler-Nędza et al. (2013) reported that the SNP g.1426G $>$ A in $M C 4 R$ significantly affects the fat and solid content of colostrum in dam-line pigs. Our results imply that a heterozygous genotype at g. $1104 \mathrm{C}>\mathrm{T}$ results in better performance than the homozygous genotype for milk yield, whereas the homozygous genotype presented higher protein percentage and fat percentage in buffaloes.

In summary, eight SNPs were identified in the buffalo $M C 4 R$ gene in this study. The three SNPs H1 (AGT), H2 (GAT), and H3 (GAC) accounted for $93.0 \%$ of 332 buffaloes. Both g.226C $>$ T and g. 1525A $>$ G were not in HWE, whereas the genotypic and allelic frequencies of the other six SNPs were consistent with HWE $(\mathrm{P}>0.05)$. The SNP g. 1104C $>$ T was significantly associated with milk yield, protein, and fat percentage $(\mathrm{P}<0.05)$. Our results provide evidence that the $M C 4 R$ gene might have potential effects on milk production traits.

\section{Conflicts of interest}

The authors declare no conflict of interest.

\section{ACKNOWLEDGMENTS}

Research supported by the National International Technology Cooperation Project (\#2014DFA31970), the Scientific Project of Guangxi Aquatic Animal Husbandry and Veterinary Bureau (\#1304512), and the Opening Project of Guangxi Key Laboratory of Buffalo Genetics, Reproduction and Breeding (\#SNKF-2012-03).

\section{REFERENCES}

Barb CR, Robertson AS, Barrett JB, Kraeling RR, et al. (2004). The role of melanocortin-3 and -4 receptor in regulating appetite, energy homeostasis and neuroendocrine function in the pig. J. Endocrinol. 181: 39-52. http://dx.doi. org/10.1677/joe.0.1810039

Barrett JC, Fry B, Maller J and Daly MJ (2005). Haploview: analysis and visualization of LD and haplotype maps. Bioinformatics 21: 263-265. http://dx.doi.org/10.1093/bioinformatics/bth457

Cai X, Mipam TD, Zhao FF and Sun L (2015). SNPs detected in the yak MC4R gene and their association with growth 
traits. Animal 9: 1097-1103. http://dx.doi.org/10.1017/S1751731115000397

Chambers JC, Elliott P, Zabaneh D, Zhang W, et al. (2008). Common genetic variation near MC4R is associated with waist circumference and insulin resistance. Nat. Genet. 40: 716-718. http://dx.doi.org/10.1038/ng.156

Choi YH, Li C, Page K, Westby A, et al. (2003). Melanocortin receptors mediate leptin effects on feeding and body weight but not adipose apoptosis. Physiol. Behav. 79: 795-801. http://dx.doi.org/10.1016/S0031-9384(03)00205-1

Dubey PK, Goyal S, Kumari N, Mishra SK, et al. (2013). Genetic diversity within 5'upstream region of Toll-like receptor 8 gene reveals differentiation of riverine and swamp buffaloes. Meta Gene 1: 24-32. http://dx.doi.org/10.1016/j. mgene.2013.08.001

Foulkes AS (2009) Applied statistical genetics with R: for population-based association studies. Springer-Verlag, New York.

Gil FM, de Camargo GM, Pablos de Souza FR, Cardoso DF, et al. (2013). Polymorphisms in the ghrelin gene and their associations with milk yield and quality in water buffaloes. J. Dairy Sci. 96: 3326-3331. http://dx.doi.org/10.3168/ jds.2012-6362

Huang M, Gao X, Li JY, Ren HY, et al. (2010). Polymorphisms in MC4R gene and correlations with economic traits in cattle. Mol. Biol. Rep. 37: 3941-3944. http://dx.doi.org/10.1007/s11033-010-0051-0

Hunt R, Sauna ZE, Ambudkar SV, Gottesman MM, et al. (2009). Silent (synonymous) SNPs: should we care about them? Methods Mol. Biol. 578: 23-39. http://dx.doi.org/10.1007/978-1-60327-411-1_2

Li C, Sun DX, Jiang L, Liu JF, et al. (2012). [Advances on genome-wide association study for economically important traits in dairy cattle]. Yi Chuan 34: 545-550. http://dx.doi.org/10.3724/SP.J.1005.2012.00545

Liu H, Tian W, Zan L, Wang H, et al. (2010). Mutations of MC4R gene and its association with economic traits in Qinchuan cattle. Mol. Biol. Rep. 37: 535-540. http://dx.doi.org/10.1007/s11033-009-9706-0

Pauciullo A, Cosenza G, Steri R, Coletta A, et al. (2012). An association analysis between OXT genotype and milk yield and flow in Italian Mediterranean river buffalo. J. Dairy Res. 79: 150-156. http://dx.doi.org/10.1017/ $\underline{\mathrm{S} 0022029911000914}$

Piórkowska K, Tyra M, Rogoz M, Ropka-Molik K, et al. (2010). Association of the melanocortin-4 receptor (MC4R) with feed intake, growth, fatness and carcass composition in pigs raised in Poland. Meat Sci. 85: 297-301. http://dx.doi. org/10.1016/j.meatsci.2010.01.017

Razquin C, Marti A and Martinez JA (2011). Evidences on three relevant obesogenes: MC4R, FTO and PPAR $\gamma$. Approaches for personalized nutrition. Mol. Nutr. Food Res. 55: 136-149. http://dx.doi.org/10.1002/mnfr.201000445

Seeley RJ, Drazen DL and Clegg DJ (2004). The critical role of the melanocortin system in the control of energy balance. Annu. Rev. Nutr. 24: 133-149. http://dx.doi.org/10.1146/annurev.nutr.24.012003.132428

Seong J, Suh DS, Park KD, Lee HK, et al. (2012). Identification and analysis of MC4R polymorphisms and their association with economic traits of Korean cattle (Hanwoo). Mol. Biol. Rep. 39: 3597-3601. http://dx.doi.org/10.1007/s11033$\underline{011-1133-3}$

Song XM, Jiang JF, Zhang GZ, Shi FX, et al. (2012). DNA polymorphisms of the Hu sheep melanocortin-4 receptor gene associated with birth weight and 45-day weaning weight. Genet. Mol. Res. 11: 4432-4441. http://dx.doi. org/10.4238/2012.September.27.3

Szyndler-Nędza M, Tyra M, Ropka-Molik K, Piórkowska K, et al. (2013). Association between LEPR and MC4R genes polymorphisms and composition of milk from sows of dam line. Mol. Biol. Rep. 40: 4339-4347. http://dx.doi. org/10.1007/s11033-013-2524-4

Van den Maagdenberg K, Stinckens A, Claeys E, Seynaeve M, et al. (2007). The Asp298Asn missense mutation in the porcine melanocortin-4 receptor ( MC4R) gene can be used to affect growth and carcass traits without an effect on meat quality. Animal 1: 1089-1098. http://dx.doi.org/10.1017/S1751731107000456

Vislovukh A, Vargas TR, Polesskaya A and Groisman I (2014). Role of 3'-untranslated region translational control in cancer development, diagnostics and treatment. World J. Biol. Chem. 5: 40-57. http://dx.doi.org/10.4331/wjbc. $\underline{\mathrm{v} 5.11 .40}$

Yan LJ, Fang XT, Liu Y, Zhang CL, et al. (2013). Effects of single and combined genotypes of MC4R and POU1F1 genes on two production traits in Langshan chicken. Mol. Biol. Rep. 40: 4645-4650. http://dx.doi.org/10.1007/s11033-013-2558-7

Zeng R, Zhang Y and Du P (2014). SNPs of melanocortin 4 receptor (MC4R) associated with body weight in Beagle dogs. Exp. Anim. 63: 73-78. http://dx.doi.org/10.1538/expanim.63.73

Zhang CL, Wang YH, Chen H, Lan XY, et al. (2009). Association between variants in the 5'-untranslated region of the bovine MC4R gene and two growth traits in Nanyang cattle. Mol. Biol. Rep. 36: 1839-1843. http://dx.doi. org/10.1007/s11033-008-9388-Z

Zuo B, Liu G, Peng Y, Qian H, et al. (2014). Melanocortin-4 receptor (MC4R) polymorphisms are associated with growth and meat quality traits in sheep. Mol. Biol. Rep. 41: 6967-6974. http://dx.doi.org/10.1007/s11033-014-3583-x 